\title{
PENGARUH KESADARAN MEREK RITEL, ASOSIASI MEREK RITEL, KUALITAS YANG DITERIMA MEREK RITEL, KESETIAAN MEREK RITEL TERHADAP EKUITAS MEREK RITEL (Studi Empiris pada Kartika Sari)
}

\author{
Ongky Alex Sander \\ Fakultas Ilmu Sosial dan Humaniora, Universitas Bunda Mulia \\ osander@bundamulia.ac.id \\ Fahrul Riza \\ Fakultas Ilmu Sosial dan Humaniora, Universitas Bunda Mulia \\ friza@bundamulia.ac.id
}

\begin{abstract}
This study examined the antecendets of Customer Based Retail Brand Equity (CBRE) such as retail brand awareness, retail brand association, retail brand perceived quality and retail brand loyalty on retail brand equity. Results of testing the hypothesis (t-test) found that variables retail brand awareness and retail brand association does not significantly influence on retail brand equity. While the other variables are retail brand perceived quality and retail brand loyalty has significantly influence on retailer brand equity. Retail brand perceived quality and retail brand loyalty must be considered by the retail businesses because it has a greater influence in creating the Retail Brand Equity (RBE). For further research, can develop research models such as the effect of brand building activities to the comunity identificatiion retailer with retail customer based equity as a mediating variable

Keywords: Customer Based Retail Brand Equity (CBRE), retail brand association, retail brand perceived quality and retail brand loyalty on retail brand equity
\end{abstract}

\begin{abstract}
ABSTRAK
Penelitian ini menguji faktor-faktor yang memengaruhi ekuitas merek ritel dari sisi konsumen yang meliputi kesadaran merek ritel, asosiasi merek ritel, kualitas merek ritel yang dipersepsikan, loyalitas terhadap merek ritel. Hasil pengujian hipotesis membuktikan secara empiris bahwa kesadaran merek ritel, asosiasi merek ritel tidak berpengaruh signifikan terhadap ekuitas merek ritel, sementara kualitas merek ritel yang dipersepsikan dan loyalitas terhadap merek ritel berpengaruh signifikan terhadap ekuitas merek ritel., sehingga kedua variabel ini penting untuk dipertimbangkan oleh para pebisnis ritel. Penelitian selanjutnya disarankan untuk meneliti tentang pengaruh dari aktivitas membangun merek terhadap identifikasi komunitas peritel dengan ekuitas merek ritel dari sisi konsumen sebagai variabel mediasi.

Kata Kunci: Ekuitas merek ritel dari sisi konsumen, kesadaran merek ritel, asosiasi merek ritel, kualitas merek ritel yang dipersepsikan, loyalitas terhadap merek ritel
\end{abstract}

\section{PENDAHULUAN}

Dalam persaingan bisnis yang ketat penting bagi setiap pelaku usaha ritel (retailer) membangun kesadaran atas mereknya.

Customer Based Retail Equity (CRBE) merupakan variabel untuk mengukur kinerja dari suatu ritel dengan cara mengukur ingatan dari konsumen akan sebuah merek ritel tertentu. Hasil pengukuran menunjukkan seberapa tinggi tingkat ekuitas dari merek ritel yang ada didalam benak konsumen (Pappu and Quester, 2008 dalam Das, 2014).

Dengan dicapainya ekuitas yang tinggi maka produk yang dipasarkan oleh ritel tersebut maka produk atau jasa akan memiliki keunggulan kompetitif sehingga peritel mempunyai kesempatan untuk menetapkan harga yang premium sehingga akan mendorong pencapaian profit yang lebih tinggi. 
Terdapat empat dimensi utama yang membentuk kuat atau tidaknya $C B R E$ ini yaitu kesadaran merek ritel, asosiasi merek ritel, kualitas yang diterima merek ritel, kesetiaan merek ritel (Pappu and Quester, 2006; Carpenter and Tybout, 1998 dalam Das et.al, 2012).

Menurut Keller 2003 dalam Musekiwa et.al (2013), kesadaran akan suatu ritel merupakan kemampuan untuk mengidentifikasi suatu merek ritel didalam perbedaan yang terkait dengan nama, logo dan lain-lain. Asosiasi suatu merek ritel menandakan segala sesuatu yang memiliki hubungan dengan suatu ritel yang terdapat dalam ingatan seseorang (Aaker 1991). Kualitas yang diterima merek ritel merupakan keseluruhan persepsi dari konsumen mengenai kualitas dari produk atau jasa dengan membandingkan penawaran yang dilakukan oleh pesaing (Aaker, 1991).

Kesetiaan akan sebuah merek ritel melambangkan pikiran yang konstruktif terhadap merek suatu ritel yang mengarah ke pembelian yang konstan suatu produk dari waktu ke waktu (Aaker, 1991). Pappu dan Quester (2006) meneliti tentang Customer Based Retail Brand Equity dari department store dipengaruhi oleh 4 dimensi yaitu retailer brand awareness, retailer brand association, retailer brand perceived quality dan retailer brand loyalty. Namun penelitian lain yang dilakukan oleh Musekiwa et.al (2013) pada OK Supermarket menemukan bahwa Customer Based Retail Brand Equity hanya dipengaruhi oleh retailer brand awareness, retailer brand perceived quality dan retailer brand loyalty. Dari kedua hasil penelitian ini terdapat perbedaan hasil penelitian mengenai dimensi yang mempengaruhi terbentuknya Customer Based Retail Brand Equity.

Empat puluh satu tahun bergelut di dalam dunia bisnis makanan, menjadikan Kartika Sari sebagai "trademark" dari kota Bandung (kartikasari.com). Meskipun masih dalam suatu lingkup daerah saja, namun dapat dikatakan bahwa Kartika Sari ini sudah memberikan banyak pengaruh yang cukup baik terhadap industri makanan khususnya oleh-oleh di Bandung. Ditandai dengan menculnya industri-industri baru yang menawarkan produk serupa dengan merek yang berbeda yang meningkatkan intensitas persaingan di bisnis oleh-oleh khas Bandung ini. Bertambahnya peritel serupa menjadi ancaman secara langsung maupun tidak langsung bagi Kartika Sari. Sehingga, hal ini menuntut Kartika Sari untuk terus menciptakan dan memberikan yang terbaik kepada konsumen, untuk itu diperlukannya ekuitas merek ritel yang kuat bagi Kartika Sari.

Pelancong lokal yang mengunjungi kota Bandung memiliki kesadaran merek yang tinggi terhadap merek Kartika Sari sehingga menjadi trademark dari kota Bandung. Kartika Sari mempunyai asosiasi ritel yang kuat bagi konsumennya sehingga dapat membentuk persepsi yang positif dari konsumen dimana "belum pernah ke Bandung jika tidak datang ke Kartika 
Sari". Hal ini secara tidak langsung akan mendorong calon konsumen untuk melakukan pembelian di Kartika Sari.

Berdasarkan dari fenomena diatas serta dengan adanya perbedaan hasil penelitian oleh beberapa peneliti terdahulu, maka peneliti tertarik untuk untuk melihat apakah dimensi dari Customer Based Retail Brand Equity berpengaruh terhadap pembentukan ekuitas merek ritel Kartika Sari sebagai gerai yang menjual oleh-oleh khas Bandung.

\section{TINJAUAN PUSTAKA}

\section{Ekuitas Merek}

Utami (2014) mendefinisikan ekuitas merek sebagai nilai yang ditawarkan oleh citra merek itu kepada suatu ritel tersebut sehingga ritel yang mempunyai ekuitas merek yang kuat bisa mendongkrak mereknya agar terjadi perluasan merek. Musekiwa et.al (2013) ekuitas merek merupakan kekuatan dari suatu merek untuk membangun ingatan konsumen berdasarkan apa yang mereka pelajari, lihat, rasakan dan dengar mengenai merek tersebut.

Ekuitas merek merupakan faktor yang cukup krusial untuk menghasilkan laba didalam suatu perusahaan. Ekuitas merek yang kuat dapat mendorong perusahaan untuk menciptakan harga yang tinggi, menciptakan dan mengontrol pangsa pasar, siklus hidup produk yang lebih panjang, memperluas produk baru, menarik investor dan juga menghindari persaingan. (Keller, 1993).
Semakin banyaknya penelitian yang dilakukan, konsep ekuitas merek kemudian diaplikasikan dan dibahas dalam retail branding (Moller dan Herm, 2013; Das et. al, 2012; Das, 2015). Merek ritel diartikan reatiler sebagai merek (Zentes et.al, 2008; Ailawadi and Keller, 2004; Das, 2015) dimana ini merupakan salah satu unsur yang paling penting untuk melakukan retail branding (Grewal et.al, 2004 dalam Das, 2015). Merek ritel dapat didefinisikan sebagai sekelompok outlet pengecer yang mempunyai suatu keunikan seperti nama, simbol, logo ataupun kombinasi dari semuanya (Zentes et.al, 2008, p. 167 dalam Das, 2015).

Berbagai penelitian menjelaskan bahwa merek ritel juga memiliki ekuitas (Das et.al, 2012; Pappu and Quester, 2008; Das, 2015) yang juga sering disebut dengan ekuitas pengecer berdasarkan konsumen atau dikenal dengan istilah Consumer Based Retail Brand Ekuitas (CBRE) (Das et.al, 2012; Pappu et.al, 2005; Das, 2015). $C B R E$ melibatkan ingatan mengenai suatu merek ritel tertentu yang ada didalam benak konsumen dimana ekuitas riteler ini merupakan hal yang penting untuk mengukur kinerja dari riteler (Pappu and Quester, 2008; Das, 2015).

Dalam teori model ekuitas merek dimana terdapat empat dimensi yaitu kesetiaan merek, kesadaran merek, kualitas yang diterima, dan asosiasi merek (Aaker, 1991). Namun pada penelitian keempat dimensi tersebut akan diadaptasikan ke dalam dunia ritel yang disetarakan menjadi 
kesadaran merek ritel, asosiasi merek ritel, kualitas yang diterima merek ritel dan kesetiaan merek ritel (Pappu and Quester, 2006; Musekiwa et.al 2013; Das et.al, 2012)

\section{Kesadaran Merek Ritel}

Kesadaran suatu merek ritel merupakan kemampuan untuk mengidentifikasi suatu merek ritel didalam perbedaan yang terkait dengan nama, logo, simbol, dan lain-lain yang ditanam dalam benak kosnumen (Keller 2003 dalam Musekiwa et.al 2013; Tong dan Hawley, 2009).

Kesadaran merek ritel ini tidak hanya meliputi kemampuan konumen untuk mengingat nama dari suatu ritel namun juga pengalaman konsumen dengan suatu merek ritel sebelumnya (Gringarten, 2013).

Menurut Christina Widya Utami (2014, p.251) menyatakan bahwa kesadaran ritel adalah kemampuan calon pelanggan untuk mengenali atau mengingat suatu merek ritel maupun produk atau jasa. Kesadaran merek membutuhkan jangkauan rangkaian kesatuan dari perasaan yang tidak pasti bahwa merek tersebut merupakan satu-satunya merek ritel dalam suatu kelompok produk.

Rangkaian kesatuan ini dapat terwakili dalam tingkatan kesadaran merek ritel yang berbeda dimana kesadaran akan merek ritel mempunyai beberapa tingkatan yaitu: retail brand recognition dan retail brand recall (Rossiter \& Percy, 1997; Sanyal \& Datta, 2011). Retail brand recognition adalah kemampuan kosnumen untuk mengingat kembali pengalaman sebelumnya dengan suatu merek ritel. Sedangkan retail brand recall adalah kemampuan konsumen untuk mengingat kembali suatu merek ritel diberikan kategori suatu produk. Jika suatu merek ritel sudah ada dalam benak konsumen akan mempengaruhi kosnumen dalam mengambil keputusan, oleh karena itu kedua tingkatan ini mempunyai peran penting dalam proses pengambilan keputusan oleh konsumen (Keller, 1993; Gringarten, 2013).

Retail brand awareness dapat terbagi menjadi retail recognition dan retail recall. Konsumen mengambil keputusan pembelian atas dasar dirinya masingmasing berdasarkan pada "membeli suatu produk dari apa yang mereka dengar" atau "memilih produk dari apa yang mereka ketahui" (Keller,1993; Musekiwa et.al 2013). Atilgan et.al (2005) berpendapat bahwa ekuitas merek ritel terjadi ketika konsumen merasa sadar dan mengetahui bahwa ritel tersebut berada pada level tertinggi dan memiliki berbagai keuntungan serta asosiasi merek yang unik didalam benak konsumen. Brand recognition cukup penting untuk produk baru, sedangkan brand recall penting untuk produk-produk yang sudah terkenal (Aaker,1996 dalam Musekiwa et.al 2013). Hasil sebuah penelitian menyatakan bahwa kesadaran merek ritel mempunyai pengaruh yang terhadap ekuitas merek ritel (Yoo et.al 2000;2006 dalam Musekiwa et.al 2013).

Penelitian lainnya menjelaskan bahwa kesadaran merek ritel adalah atribut yang 
fundamental dari pembentukan ekuitas merek ritel (Aaker, 1991; Aaker, 1996; Tong \& Hawley, 2009; Severi dan Ling, 2013) sehingga hal itu dapat mempengaruhi persepsi dan sikap konsumen. (Huang \& Sarigollu, 2011). Menurut Tong dan Hawley (2009) menjelaskan bahwa retail brand awareness merupakan komponen penting untuk pembentukan ekuitas merek ritel . Sedangkan jika menurut Keller (2008) bahwa CBRE terjadi ketika konsumen memiliki kesadaran yang tinggi dan terbiasa akan merek ritel tersebut.

$\mathrm{H} 1$ : retail brand awareness memiliki pengaruh yang signifikan terhadap ekuitas merek ritel

\section{Asosiasi Merek Ritel}

Asosiasi merek ritel sebagai segala sesuatu yang memiliki hubungan dengan ritel yang terdapat pada ingatan seseorang (Aaker 1991; Atilgan et.al 2005). Asosiasi merek ritel juga bisa membantu proses konsumen dalam mengingat informasi atau bisa dikatakan sebagai penentu ketidaksamaan dan tambahannya untuk membuat alasan pembelian serta menciptakan pendapat positif terhadap suatu ritel (Aaker 1992; Lee et.al, 2011). Asosiasi merek ritel mempunyai peran yang penting untuk keberhasilan suatu merek ritel serta juga membantu untuk menciptakan citra merek ritel dan reputasi yang baik. (Gringarten, 2013).

Asosiasi merek ritel mempunyai dua kategori yaitu asosiasi produk dan asosiasi organisasional Chen (2001). Asosiasi produk dapat meliputi asosiasi fungsional dan non-fungsional. Definisi dari asosiasi fungsional adalah fitur nyata dari suatu produk (Keller 1993; Y.L dan Lee, 2011). Sedangkan jika asosiasi non-fungsional meliputi fitur simbolik (Y.L dan Lee, 2011) yang merupakan fitur yang tak berwujud untuk memenuhi kebutuhan konsumen berupa pengakuan sosial, ekspresi diri atau harga diri (Y.L dan Lee, 2011). Asosiasi organisasional kemampuan asosiasi perusahaan dimana asosiasi yang terkait seperti kemampuan perusahaan dalam memproduksi dan mengirim output serta program CSR (Coorporate Social Responsibility) (Y.L dan Lee, 2011).

Asosiasi merek ritel menjadi bagian inti untuk membangun ekuitas merek ritel yang kuat (Musekiwa et.al 2013). Ini dapat terbagi menjadi product association dan organisational association. Product association dapat meliputi harga, kualitas dan kegunaan suatu produk. Sedangkan organisational association dapat meliputi kemampuan perusahaan maupaun program CSR (Coorporate Social Responsibility). Penelitian membuktikan bahwa asosiasi merek ritel mempunyai pengaruh yang positif terhadap ekuitas merek ritel. (Musekiwa et.al 2013).

Menurut Aaker (1991) mempercayai bahwa asosiasi merek ritel dan ekuitas merek ritel mempunyai keterikatan yang kuat dan positif antara satu sama lain, karena dianggap sebagai kualitas dan komitmen sehingga akan mempengaruhi 
konsumen agar terbiasa dengan suatu ritel. Menurut Aaker (1991) menjelaskan CBRE dapat terjadi jika konsumen dapat menyimpan keunikan dari asosiasi ritel dalam benak konsumen.

$H 2$ : asosiasi merek ritel memiliki pengaruh yang signifikan terhadap ekuitas merek ritel.

\section{Kualitas Yang Diterima Merek Ritel}

Kualitas yang diterima merek ritel adalah penilaian psikologis dari konsumen mengenai suatu produk berdasarkan persepsi masing-masing konsumen (Saleem et.al 2015). Sedangkan jika menurut Aaker (1991) kualitas yang diterima merek ritel dapat didefinisikan sebagai keseluruhan persepsi dari konsumen mengenai kualitas dari produk atau jasa dengan membandingkan penawaran yang dilakukan oleh pesaing.

Perceived quality ke dalam dua kategori yaitu sifat intrinsik dan ekstrinsik (Zeithmal, 1988; Steenkamp, 1997). Sifat intrinsik berkaitan dengan bentuk fisik dari suatu produk seperti warna, rasa, bentuk dan penampilan. Sedangkan jika sifat ekstrinsik berhubungan dengan produk namun tidak berhubungan langsung dengan aspek fisik dari suatu produk seperti harga, nama merek, kemasan dan informasi mengenai produk (Bernue's et.al 2003)

Keller (2008, p.195) mengartikan kualitas yang diterima merek ritel sebagai persepsi konsumen terhadap kualitas keseluruhan atau keunggulan produk atau jasa yang dibandingkan dengan pilihan dan dengan tujuan yang ditetapkan.

Dimensi perceived quality menurut Keller (2008, p.195) adalah, performance (kinerja), karakter utama sebagai tingkat operasional produk. Feature (fitur), elemen kedua yang melengkapi karakter utama produk. Conformance Quality (kesesuaian kualitas), tingkat dimana sebuah produk sesuai dengan spesifikasi yang telah dibuat. Reliability (reliabilitas), konsistensi kinerja produk ketika konsumen mengkonsumsi secara berkala. Durability (daya tahan), kesesuaian harapan pelanggan dengan nilai ekonomis produk. Serviceability (kemampuan layanan), kemudahan konsumen dalam mendapatkan pelayanan atas pembelian produk. Style and design (gaya dan desain), wujud atau perasaan yang dirasakan konsumen tentang kualitas.

Kualitas yang diterima merek ritel dianggap sebagai bagian dimensi pada Customer Based Retail Brand Equity (Aaker, 1996). Jones et.al (2002) mengatakan terdapat pengaruh secara langsung antara kualitas yang diterima merek ritel dan pembelian kembali serta rekomendasi dan perlawanan untuk alternatif yang lebih baik merupakan inti dari ekuitas merek ritel. Terdapat teori yang menjelaskan bahwa kualitas yang diterima merek ritel secara langsung mempengaruhi ekuitas merek ritel (Umar et.al 2012; Nguyen, 2012; Nguyen et.al, 2011; Loureiro and Fransisco, 2011; Erenkol and Duygun, 2010; Musekiwa et.al 2013). 
Salah satu unsur penting dalam pembentukan ekuitas merek ritel adalah kualitas yang diterima merek ritel (Aaker, 1996). Disisi lainnya, menurut Yoo (2000) menjelaskan bahwa ekuitas merek ritel akan meningkat jika memiliki kualitas yang diterima merek ritel yang positif.

H3 : kualitas yang diterima merek ritel memiliki pengaruh yang signifikan terhadap ekuitas merek ritel

\section{Kesetiaan Merek Ritel}

Aaker (1991) mendefinisikan kesetiaan akan sebuah ritel melambangkan pikiran yang konstruktif terhadap merek suatu ritel yang mengarah ke pembelian yang konstan suatu produk dari waktu ke waktu. Loyalitas merek merupakan elemen penting ketika datang untuk mengevaluasi merek ritel terutama dalam mengenai nilai karena loyalitas dapat menghasilkan keuntungan (Aaker, 1991; Severi dan Ling, 2013)

\section{Grembler dan Brown (1996)} mendefinisikan loyalitas ke dalam dua pengertian yang berbeda. Yang pertama, loyalitas berdasarkan sikap yaitu berhubungan dengan perilaku konsumen dimana hal ini ditandai dengan indikasi melakukan pembelian kembali (Keller, 1998) atau komitmen untuk melakukan pembelian ulang akan merek tersebut sebagai pilihan utama (Oliver 1997, 1999). Sedangkan loyalitas kognitif muncul ketika suatu merek tersebut yang pertama kali muncul dalam benak konsumen dan ketika ingin melakukan pembelian akan merek tersebut hal itu merupakan pilihan utama dari konsumen tersebut (Keller, 1998).

Loyalitas seringkali dikaitkan dengan perilaku pembelian ulang, namun dalam konteks ritel, loyalitas mencerminkan komitmen psikologis terhadap ritel tertentu (Tjiptono dan Chandra, 2012). Sehingga konsumen yang loyal pada sebuah ritel secara psikologis, walaupun tidak menunjukkan perilaku pembelian ulang.

Aaker (1991) berpendapat bahwa ekuitas merek ritel merupakan bagian dari pemasaran yang berujuan untuk menciptakan kesetiaan pelanggan dengan cara meningkatakan emosi pelanggan, asosiasi merek dan lainnya. Banyak penelitian menjelaskan bahwa ekuitas dapat mempengaruhi kesetiaan pelanggan secara langsung, namun Gustafsson and Johnson (2002) mengatakan bahwa ekuitas merek ritel mempengaruhi kesetiaan secara tidak langsung karena hal itu tergantung pada pengalaman konsumen tentang ritel tersebut dan pengalaman tersebut akan menciptakan kesetiaan pelanggan. Pernyataan lebih lanjut dari Keller (1998) bahwa salah satu karakterisitik ritel yang memiliki ekuitas merek ritel yang kuat adalah memiliki kesetiaan merek ritel yang kuat juga. Aaker (1991)) juga mendukung pendapat ini dengan mempertegas bahwa kesetiaan merek ritel dapat bergantung baik pada dimensi maupun hasil dari ekuitas merek ritel itu sendiri.

Menurut Marshall (2010) bahwa kesetiaan merek ritel merupakan suatu pemikiran dimana perusahaan menekankan 
baik itu dengan cara membangun atau mempertahankan kunjungan konsumen dalam jangka panjang, sehingga dapat meningkatkan kesetiaan merek ritel, dengan demikian kesetiaan merek ritel menjadi jantung dari pembentukan ekuitas merek ritel .

\section{METODE PENELITIAN}

Objek penelitian yang diteliti adalah kesadaran merek ritel, asosiasi merek ritel, kualitas yang diterima merek ritel, kesetiaan merek ritel dan ekuitas merek ritel dari konsumen Kartika Sari. ). Subjek dari penelitian ini akan difokuskan kepada konsumen yang pernah mengunjungi dan melakukan transaksi di Kartika Sari. Jenis penelitian yang dilakukan adalah causal research. Penelitian menggunakan data primer dan teknik pengumpulan data yang digunakan adalah kuesioner.
Peneliti memggunakan kuesioner yang disebarkan secara online dan offline. Untuk penyebaran kuesioner secara offline peneliti mencetak kuesioner penelitian yang kemudian memberikan kuesioner tersebut secara langsung kepada responden. Sedangkan kuesioner secara online yang dibuat menggunakan fasilitas google form dan cara penyebarannya melalui berbagai media sosial seperti blackberry messanger (BBM), path, facebook, LINE, dan instagram, 


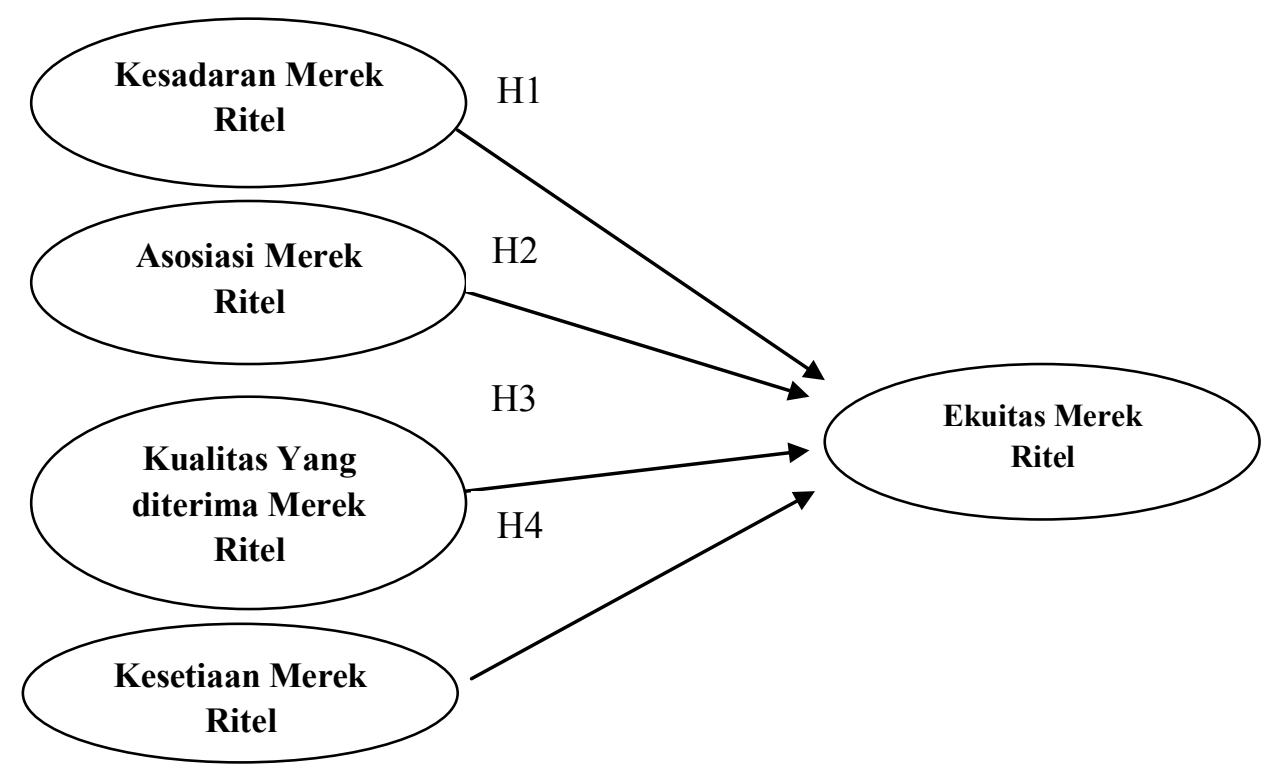

Gambar 1. Paradigma Penelitian

Sumber : Adaptasi dari Musekiwa, Douglas dan Hope (2013)

Populasi yang digunakan dalam melakukan penelitian ini merupakan responden yang potensial yang pernah mengunjungi dan melakukan transaksi di Kartika Sari Bandung, dan teknik pengambilan sampel yang digunakan oleh peneliti yaitu teknik pengambilan sampel non-probabilitas.

Alat pengolahan data yang digunakan yaitu SPSS 20 dalam menganalisis data yang ada seperti melakukan uji validitas, uji reliabilitas, uji asumsi klasik. Uji F, koefisien determinasi $\left(\mathrm{R}^{2}\right)$, analisis regresi, maupun uji t (signifikansi).

\section{Definisi Variabel Penelitian Secara Operasional}

\begin{tabular}{lrcr}
\multicolumn{2}{c}{ Variabel yang } & terdapat & dalam \\
penelitian ini dapat & dijelaskan & dalam \\
definisi & konseptual & dan & definisi \\
operasional. Definisi & konseptual dan
\end{tabular}

definisi operasional dari masing-masing variabel yang terdapat dalam penelitian ini dijabarkan sebagai berikut:

Kesadaran merek ritel: kemampuan untuk mengidentifikasi suatu ritel didalam perbedaan terkait dengan nama, logo, simbol dan lain-lain yang ditanam dalam benak konsumen (Keller 2003, dalam Musekiwa et.al 2013)

- Saya mengingat produk yang saya beli di Kartika Sari.

- Ketika saya ingin membeli oleholeh di Bandung, Kartika Sari merupakan pilihan utama saya.

- Saya sering melihat iklan Kartika Sari

- Toko Kartika Sari terlihat jelas dari luar.

- Saya mengetahui semua promosi yang dilakukan Kartika Sari. 
Asosiasi merek ritel: Segala sesuatu yang memiliki hubungan dengan ritel yang terdapat dalam ingatan seseorang ( Aaker 1991)

- Jika Kartika Sari sebuah mobil, itu diibaratkan sebagai Marcedez Benz (menggambarkan kemewahan).

- Jika Kartika Sari seekor hewan, itu diibaratkan seekor singa (menggambarkan kekuatan yang besar.

- Mempunyai peran yang penting terhadap kesuksesan Kartika Sari.

- Kartika Sari selalu mementingkan kualitas yang diterima oleh konsumen

Kualitas yang diterima merek ritel: Persepsi seorang konsumen terhadap kualitas secara keseluruhan atau keunggulan atas sebuah ritel yang sesuai dengan tujuan yang dikehendaki, yang berhubungan dengan pilihan.

- Staff di Kartika Sari melayani dengan sopan

- Staff di Kartika Sari selalu melayani konsumen dengan baik

- Staff di Kartika Sari terlihat rapi

- Desain promosi yang digunakan modern

- Peralatan promosi yang digunakan modern.

- Pelayanan yang diberikan Kartika Sari cepat.

- Kartika Sari memiliki jam operasional yang baik.
- Kartika Sari memiliki bermacam macam produk.

- Produk-produk Kartika Sari mempunyai kualitas yang baik

Kesetiaan merek ritel: Suatu komitmen yang kuat dari konsumen untuk melakukan pembelian ulang maupun mengunjungi kembali suatu ritel dalam berbagai kondisi (Oliver, 1999)

- Saya percaya terhadap Kartika Sari

- Saya akan merekomendasikan Kartika Sari kepada teman dan keluarga saya.

- Saya tidak akan berpindah ke toko lain selain Kartika Sari.

- Saya hanya akan membeli produk dari Kartika Sari

Ekuitas merek ritel: Kekuatam dari suatu ritel untuk membangun ingatan konsumen berdasarkan apa yang mereka pelajari, lihat, rasakan dan dengar mengenai ritel tersebut.

- Kartika Sari lebih menarik dibandingkan yang lainnya.

- Saya sangat menghargai merek Kartika Sari.

- Saya memiliki perasaan yang positif terhadap Kartika Sari.

- Meskipun kompetitor menawarkan layanan yang sama, saya tetap memilih Kartika Sari karena itu adalah pilihan logis bagi saya. 
PEMBASAN DAN HASIL

Nilai standar yang digunakan untuk melihat apakah suatu instrumen valid atau tidak adalah sebesar 0,3 . Nilai korelasinya lebih besar dari 0,3 maka dapat dinyatakan bahwa faktor tersebut mempunyai nilai konstruk yang kuat (Sugiyono, 2010).

Tabel 1. Uji Validitas

\begin{tabular}{|c|c|c|c|}
\hline Indikator & $\begin{array}{c}\text { Correct } \\
\text { ed } \\
\text { Item- } \\
\text { Total } \\
\text { Correla } \\
\text { tion }\end{array}$ & $\begin{array}{c}\text { Cut } \\
\text { Off } \\
(r> \\
(\boldsymbol{r}, 30)\end{array}$ & Intepretasi \\
\hline RA1 & .332 & .30 & VALID \\
\hline RA2 & .366 & .30 & VALID \\
\hline RA3 & .548 & .30 & VALID \\
\hline RA4 & .411 & .30 & VALID \\
\hline RA5 & .581 & .30 & VALID \\
\hline RAC1 & .669 & .30 & VALID \\
\hline RAC2 & .701 & .30 & VALID \\
\hline RAC3 & .644 & .30 & VALID \\
\hline RAC4 & .449 & .30 & VALID \\
\hline PQ1 & .678 & .30 & VALID \\
\hline PQ2 & .710 & .30 & VALID \\
\hline PQ3 & .687 & .30 & VALID \\
\hline PQ4 & .500 & .30 & VALID \\
\hline PQ5 & .579 & .30 & VALID \\
\hline PQ6 & .573 & .30 & VALID \\
\hline PQ7 & .518 & .30 & VALID \\
\hline PQ8 & .498 & .30 & VALID \\
\hline PQ9 & .580 & .30 & VALID \\
\hline SL1 & .641 & .30 & VALID \\
\hline SL2 & .659 & .30 & VALID \\
\hline SL3 & .782 & .30 & VALID \\
\hline SL4 & .733 & .30 & VALID \\
\hline RBE1 & .727 & .30 & VALID \\
\hline RBE2 & .668 & .30 & VALID \\
\hline RBE3 & .731 & .30 & VALID \\
\hline RBE4 & .728 & .30 & VALID \\
\hline
\end{tabular}

Sumber: Penelitian lapangan 2016

\section{Uji Validitas}

Hasil pengolahan data menggunakan SPSS ditampilkan pada tabel 2. Dapat dinyatakan bahwa semua indikator yang digunakan pada variabel kesadaran merek ritel, retailer brand association, retailer brand perceived quality, kesetiaan merek ritel dan ekuitas merek ritel dapat dikatakan valid karena nilai $r$-hitung dari keseluruhan indikator berada antara 0,332 hingga 0,782 yang berarti nilai tersebut lebih dari nilai cut off yang digunakan yaitu 0,3, sehingga dapat disimpulkan bahwa semua indikator yang digunakan dalam penelitian ini mempunyai nilai konstruk yang kuat.

\section{Uji Reliabilitas}

Uji reliabilitas ini menggunakan cronbach's alpha sebagai acuan untuk melihat reliabel atau tidak indikator. Tolak ukur nilai cronbach's alpha yang digunakan adalah lebih dari atau sama dengan 0,6 maka dapat disimpulkan bahwa seluruh instrumen sudah reliabel (Hair et.al 2013, p. 374; Malhotra, 2012, p. 317).

\section{Uji Asusmsi Klasik}

Uji statistik non-parametrik Kolmogorov-Smirnov (K-S) didapatkan bahwa nilai signifikansi (2-tailed) adalah sebesar 0,602 , dimana nilai $0,602>0,05$ sehingga dapat disimpulkan bahwa data residual berdistribusi normal pada persamaan regresi tersebut

Tabel 2. Uji Reliabilitas

\begin{tabular}{|c|c|c|}
\hline Variabel & $\begin{array}{l}\text { Cronbach's } \\
\text { Alpha }\end{array}$ & $\mathrm{N}$ of items \\
\hline $\begin{array}{l}\text { Kesadaran merek } \\
\text { ritel }\end{array}$ & .692 & 5 \\
\hline $\begin{array}{l}\text { Asosiasi merek } \\
\text { ritel }\end{array}$ & .800 & 4 \\
\hline $\begin{array}{l}\text { Kualitas yang } \\
\text { diterima merek ritel }\end{array}$ & .860 & \\
\hline $\begin{array}{l}\text { Kesetiaan merek } \\
\text { ritel }\end{array}$ & .857 & 4 \\
\hline Ekuitas merek ritel & .859 & 4 \\
\hline
\end{tabular}

Sumber: Hasil penelitian lapangan 2016.

Hasil uji glejser menunjukkan seluruh variable bebas memiliki nilai signifikan di 
atas 5\%, hal ini mengindikasikan bahwa tidak terdapat heteroskedastisitas dalam variabel yang dianalisis.

Nilai VIF dari seluruh variabel yang digunakan yaitu VIF $<10$ karena nilai VIF berada diantara 2,043 - 2,330 dan nilai Tol $>0,1$ dengan rentang nilai berkisar antara
0,429 - 0,489. Dari hasil ini dapat disimpulkan bahwa tidak terjadi multikolinearitas pada persamaan regresi tersebut hal ini menandakan bahwa tidak terjadi hubungan korelasi yang kuat antara variabel dependen.

\section{Hasil Persamaan Regresi}

Tabel 3. Hasil Regresi

\section{Coefficients $^{\mathrm{a}}$}

\begin{tabular}{|l|r|r|r|r|r|}
\hline \multirow{2}{*}{ Model } & \multicolumn{2}{|c|}{ Unstandardized Coefficients } & \multicolumn{1}{|c|}{$\begin{array}{c}\text { Standardized } \\
\text { Coefficients }\end{array}$} & \multirow{2}{*}{$\mathrm{t}$} & \\
\cline { 2 - 4 } & $\mathrm{B}$ & $\begin{array}{r}\text { Std. } \\
\text { Error }\end{array}$ & Beta & & \\
\hline (Constant) & .139 & .801 & & .174 & .862 \\
totalRA & .024 & .049 & .025 & .478 & .633 \\
totalRAC & .077 & .052 & .072 & 1.479 & .140 \\
TotalPQ & .096 & .032 & .146 & 2.970 & .003 \\
TotalSL & .658 & .050 & .669 & 13.053 & .000 \\
\hline
\end{tabular}

a. Dependent Variable: TotalRBE

Sumber: Hasil penelitian lapangan 2016

Koefisien regresi dari kesadaran merek ritel sebesar 0,024, menyatakan pengaruh yang positif terhadap ekuitas merek ritel. Koefisien regresi dari asosiasi merek ritel sebesar 0,077, menyatakan pengaruh yang positif terhadap ekuitas merek ritel. Koefisien regresi dari kualitas yang diterima merek ritel sebesar 0,096, menyatakan pengaruh yang positif terhadap ekuitas merek ritel. Koefisien regresi dari kesetiaan merek ritel sebesar 0,658, menyatakan pengaruh yang positif terhadap ekuitas merek ritel.
Nilai $\mathrm{R}^{2}$ yang dihasilkan adalah sebesar 0,701 atau $70,1 \%$. Hal ini berarti bahwa $70,1 \%$ dari variabel retail brand equity dipengaruhi oleh variabel kesadaran merek ritel, asosiasi merek ritel, kualitas yang diterima merek ritel dan kesetiaan merek ritel sedangkan sisanya sebesar $29,9 \%$ variabel ekuitas merek ritel dipengaruhi oleh variabel lain yang tidak diteliti dalam penelitian ini.

Hasil dari uji statistik F yang diperoleh dari pengolahan data responden, sehingga dihasilkan nilai $\mathrm{F}$ sebesar 149,305 dengan tingkat signifikansi sebesar 0,000 , hal ini 
menandakan bahwa nilai signifikansi yang diperoleh dibawah nilai alpha yang digunakan yaitu 0,05. Jadi dapat disimpulkan bahwa model regresi yang digunakan dalam penelitian ini yaitu kesadaran merek ritel, asosiasi merek ritel,kualitas yang diterima merek ritel dan kesetiaan merek ritel dapat memprediksi ekuitas merek ritel.

Hasil hipotesis 1, menjelaskan bahwa Ho1 tidak di tolak, hal ini dikarenakan nilai t-hitung $<$ t-tabel yaitu $0,478<1,96$ sehingga dapat disimpulkan bahwa kesadaran merek ritel tidak berpengaruh signifikan terhadap ekuitas merek ritel.

Hasil dari penelitian ini bertentangan dengan penelitian yang dilakukan oleh Musekiwa et.al (2013) dimana hasil penelitian tersebut menjelaskan terdapat pengaruh yang signifikan antara kesadaran merek ritel terhadap ekuitas merek ritel. Berbedanya hasil penelitian yang dilakukan oleh peneliti saat ini dengan peneliti sebelumnya karena terdapat perbedaan subjek penelitian dimana pada penelitian sebelumnya menggunakan subjek penelitian toko ritel berjenis grocery store sedangkan subjek penelitian yang digunakan oleh peneliti saat ini merupakan toko ritel berjenis speciality store. Disamping itu juga, kesadaran merek ritel tidak berpengaruh signifikan terhadap ekuitas merek ritel pada Kartika Sari karena kurang melakukan promosi yang berkelanjutan sehingga awareness konsumen menjadi pudar/ berkurang. Hal ini didasarkan pada penelitian yang dilakukan oleh Das, Gopal (2015) dan Musekiawa et.al (2015) yang menjelaskan bahwa retailer awareness akan tetap melekat jika mempunyai suasana toko yang baik serta melakukan aktivitas-aktivitas promosi seperti iklan, promosi penjualan, penjualan langsung, public relation (PR) dan lain sebagainya.

Hasil hipotesis 2, menjelaskan bahwa Ho1 tidak di tolak, hal ini dikarenakan nilai t-hitung $<$ t-tabel yaitu $1.479<1,96$ sehingga dapat disimpulkan bahwa asosiasi merek riteltidak berpengaruh signifikan terhadap ekuitas merek ritel.

Hasil penelitian yang dilakukan oleh peneliti saat ini juga sejalan dengan penelitian yang telah dilakukan oleh peneliti sebelumnya yaitu Musekiwa et.al (2013) dan Atilgan et.al (2005) yang menjelaskan bahwa tidak terdapat pengaruh yang signifikan antara asosiasi merek ritel terhadap ekuitas merek ritel karena menurut keduanya antara asosiasi merek ritel dan kesadaran merek ritel mempunyai hubungan dan pengaruh yang sama terhadap ekuitas merek ritel.

Hasil hipotesis 3 menjelaskan bahwa Hol di tolak, hal ini dikarenakan nilai thitung $<$ t-tabel yaitu 2,970 >1,96 sehingga dapat disimpulkan bahwa kualitas yang diterima merek ritel berpengaruh signifikan terhadap ekuitas merek ritel.

Berdasarkan hasil penelitian yang dilakukan oleh peneliti turut mendukung hasil penelitian sebelumnya (Musekiwa et.al, 2013) yang menjelaskan bahwa terdapat pengaruh yang signifikan antara 
kualitas yang diterima merek ritel terhadap ekuitas merek ritel. Hal ini dikarenakan bahwa kualitas yang diterima merek ritel merupakan unsur penting untuk pembentukan ekuitas merek ritel (Aaker, 1996) dimana menurut Yoo (2000) bahwa ekuitas merek ritel akan meningkat jika memiliki kualitas yang diterima merek ritel yang positif.

Hasil hipotesis 4 menjelaskan bahwa Hol di tolak, hal ini dikarenakan nilai thitung $>$ t-tabel yaitu $13,053>1,96$ sehingga dapat disimpulkan bahwa kesetiaan merek ritel berpengaruh signifikan terhadap ekuitas merek ritel.

Berdasarkan hasil penelitian diatas turut mendukung hasil penelitian yang dilakukan oleh penelitian sebelumnya (Musekiwa et.al, 2013) dimana terdapat pengaruh yang signifikan antara kesetiaan merek ritel terhadap ekuitas merek ritel. Hal ini dikarenakan menurut Marshall (2010) dalam Severi dan Ling (2013) dimana kesetiaan merek ritel menjadi jantung dari pembentukan ekuitas merek ritel.

\section{SIMPULAN DAN SARAN}

\section{Simpulan}

Hasil hipotesis 1, menjelaskan bahwa Hol tidak di tolak, hal ini dikarenakan nilai t-hitung $<$ t-tabel yaitu $0,478<1,96$ sehingga dapat disimpulkan bahwa kesadaran merek ritel tidak berpengaruh signifikan terhadap ekuitas merek ritel.

Hasil hipotesis 2, menjelaskan bahwa Hol tidak di tolak, hal ini dikarenakan nilai t-hitung $<$ t-tabel yaitu $1.479<1,96$ sehingga dapat disimpulkan bahwa asosiasi merek ritel tidak berpengaruh signifikan terhadap ekuitas merek ritel.

Hasil hipotesis 3 menjelaskan bahwa Hol di tolak, hal ini dikarenakan nilai thitung $<$ t-tabel yaitu 2,970 $>1,96$ sehingga dapat disimpulkan bahwa kualitas yang diterima merek ritel berpengaruh signifikan terhadap ekuitas merek ritel.

Hasil hipotesis 4 menjelaskan bahwa Hol di tolak, hal ini dikarenakan nilai thitung $>$ t-tabel yaitu $13,053>1,96$ sehingga dapat disimpulkan bahwa kesetiaan merek ritel berpengaruh signifikan terhadap ekuitas merek ritel.

\section{Saran}

Bagi dunia akademisi, sebaiknya dilakukan pengembangan yang lebih mendalam mengenai pengetahuan dan wawasan tentang cara menciptakan Customer Based Retail Equity (CBRE) yang baik didalam sebuah ritel karena adanya $C B R E$ dapat menciptakan keunggulan kompetitif. Serta dapat dijadikan materi perkuliahan pada mata kuliah pemasaran ritel dan strategi bisnis ritel.

Bagi peneliti selanjutnya, sebaiknya dilakukan penelitian yang lebih mendalam dalam hal pemilihan responden yang lebih spesifik serta dapat menggunakan subjek penelitian dalam skala yang lebih besar. Karena subjek penelitian yang digunakan oleh peneliti hanya melingkupi satu daerah tertentu. Oleh karena itu, untuk kedepannya 
dapat menggunakan subjek penelitian yang lebih luas cakupannya sehingga dapat memudahkan peneliti untuk mendapatkan responden dan mengolah data. Dan juga dapat melakukan pengembangan model penelitian seperti pengaruh brand building activities terhadap retailer comunity identificatiion dengan customer based retail equity sebagai variabel mediasi (Samu, Lyndem and Litz, 2012)

Bagi pelaku bisnis ritel, agar memperhatikan pentingnya untuk menciptakan Customer Based Retail Equity (CBRE) karena dengan memiliki CBRE yang baik maka suatu ritel dapat menciptakan keunggulan yang kompetitif sehingga dapat bersaing dalam pasar bahkan dapat menjadi pemimpin pasar dalam jenis ritel yang dijalankan. Terutama dua hal yang harus diperhatikan yaitu kualitas yang diterima merek ritel dan kesetiaan merek ritel tanpa mengesampingkan kesadaran merek ritel dan asosiasi merek ritel

Untuk terus meningkatkan kualitas yang diterima merek ritel maka pelaku bisnis ritel khususnya Kartika Sari harus memperhatikan hal-hal seperti penataan, signage, profesionalitas karyawan, layanan konsumen serta suasana toko seperti pencahayaan, warna dan lain-lain. (Musekiwa et.al).

Untuk terus meningkatkan kesetiaan merek ritel bagi pelaku bisnis ritel khususnya Kartika Sari harus menerapkan program peningkatan loyalitas (Musekiwa et.al, 2013) seperti pembuatan kartu anggota sehingga dapat meningkatkan kepercayaan konsumen akan Kartika Sari.

\section{DAFTAR PUSTAKA}

Aaker, D.A. (1991) Managing Brand Equity. New York: Free Press.

Atilgan. E, Aksoy. S, \& Akinci. S. 2005. Determinants of The Brand Equity: A Verification Approach in The Beverage Industry in Turkey. Marketing Intelligence \& Planning. Vol. 23 No.3, p237-247

Azwar, Saifuddin. 2012. Reliabilitas dan Validitas (edisi 4). Yogyakarta: Pustaka Belajar.

Bangun, Wilson, 2008. Intisari Manajemen. Bandung: Refika Aditama.

Das, Gopal; Biplab Datta and Kalyan Kumar Guin. 2012. Impact Of Retailer Personality On ConsumerBased Retailer Equity. Asia Pacific Journal of Marketing and Logistics, Vol. 24 Iss 4 pp. $619-639$.

Das, Gopal. 2015. Impact Of Store Attributes On Consumer-Based Retailer Equity. Journal of Fashion Marketing and Management, Vol. 19 Iss 2 pp. $188-204$.

Ferdinand, Agusty D. 2013. Metode penelitian Manajemen: Pedoman Penelitian Untuk Penulisan Skripsi, Tesis dan Disertasi Ilmu Manajemen. Semarang: Badan Penerbit Universitas Diponegoro.

Ghozali, Imam. 2013. Aplikasi Analisis Multivariate Dengan Program SPSS. Semarang : BP Universitas Diponegoro.

Gringarten, Hagai. 2013. Price and Store Image as Mitigating Factors in the Perception and Evaluation of Retailers' Customer-Based Brand Equity. Florida: Lynn University. 
Hair, et.al. 2006. Marketing Research: Within a Changing Information Environment 3rd Edition. New York: Mc.Graw-Hill/Irwin.

Hair, et.al. 2010. Multivariate Data Analysis. United States: Perason Pretince Hall.

Keller, K.L. 2008. Strategic Brand Management:Builiding, Measuring and Managing Brand Equity (Third Edition ed.). New Jersey: Pearson Education.

Kementerian Pariwisata dan Ekonomi Kreatif RI. 2014. Ekonomi Kreatif: Kekuatan Baru Indonesia Menuju 2025. Jakarta: Kementerian Pariwisata dan Ekonomi Kreatif RI.

Lee, H. M, Lee C.C \& Wu, C. C. 2011. Brand Image Strategy Affects Brand Equity after M\&A. Eorupean Journal of Marketing. Vol.45 No.7, p.1091-1111.

Levy, Michael; Weitz, Barton A; Grewal, Dhruv. $2014 \quad$ Retailing Management $9^{\text {th }} \quad$ edition.

New York: McGrawHill.

Mahadianto, Yudi dan Adi Setiawan. 2013. Analisis Parametrik Dependensi dengan Program SPSS: Untuk Pengolahan Data Tugas Akhir, Skripsidan Tesis. Jakarta: Rajagrafindo Persada.

Malhotra, N.K. 2012. Basic Marketing Research: Integration of Social Media International Edition. United States: Perason Pretince Hall.

Musekiwa, Albert, Douglas \& Hope. 2013. Customer Based Retail Brand Equity (RBE) Dimensions Effect on Retail Brand Equity for OK Supermarket in Bindura.

International Journal of Business and Management. Vol. 8 No.19.

Pappu, R. and Quester, P. (2006b), "Does customer satisfaction lead to improved brand equity? An empirical examination of two categories of retail brands", Journal of Product \& Brand Management, Vol. 15 No. 1, pp. 4-14.

Rambocas, Meena, Vishnu M. Kirpalani and Errol Simms. 2014. Building Brand Equity In Retail Banks: The Case Of Trinidad And Tobago. International Journal of Bank Marketing Vol. 32 No. 4, 2014 pp. 300-320.

Rangkuti, Freddy. 2007. Riset Pemasaran. Jakarta: Gramedia Pustaka Utama

Samu, Sridhar, Preeti Krishnan Lyndem and Reginald A. Litz. 2012. "Impact of brand-building activities and retailer-based brand equity on retailer brand communities". European Journal of Marketing, Vol. 46 Iss 11/12 pp. 1581 - 1601

Saleem, Salman; Saleem Ur Rahman and Ranna Muhammad Umar. 2015. Measuring Customer Based Beverage Brand Equity: Investigating the Relationship between Perceived Quality, Brand Awareness, Brand Image, and Brand Loyalty. International Journal of Marketing Studies; Vol. 7, No. 1.

Sanyal, Shamindra Nath; Saroj Kumar Datta. 2011. The Effect of Country of Origin on Brand Equity: an Empirical Study on Generic Drugs. Journal of Product and Brand Management, Vol. 20 lss 2 pp. 130140 .

Sekaran and Bougie. 2013. Research Methods for Business: a skillbuilding approach $6^{\text {th }} \mathrm{ed}$. United Kingdom: John Wiley \& Sons Ltd.

Severi, Erfan and Kwek Choon Ling. 2013. The Mediating Effects of Brand Association, Brand Loyalty, Brand Image and Perceived Quality on Brand Equity. Asian Social Science; Vol. 9, No. 3; 2013. 
Tjiptono. F \& Chandra. G. 2012. Pemasaran Strategik. Yogyakarta: Andi.

Tong, Xiao, and Jana M. Hawley. 2009. Measuring Customer-Based Brand Equity: Empirical Evidence From The Sportswear Market in China. Journal of Product \& Brand Management, Vol. 18 Iss 4 pp. 262 -271 .

Utami, Christina Widya. 2014. Manajemen Ritel: Strategi dan Implementasi Operasional Bisnis Ritel Modern di Indonesia. Jakarta: Salemba Empat.

Y.L, Chieng Fayrene and Goi Chai Lee. 2011. Customer-Based Brand
Equity: A Literature Review. Journal of Arts Science \& Commerce Vol.- II.

Zentes, Joachim; Dirk Morschett and Hanna Schramm-Klein. 2011. Strategic Retail Managementn: Text and International Cases $2^{\text {nd }}$ Edition. Wiesbaden: Gabler Verlag.

Zikmund, William; Barry J. Babin; Jon C. Carr dan Mitch Griffin. 2013. Business Research Methods $9^{\text {th }}$ Edition. South-Western: Cengage Learning. 